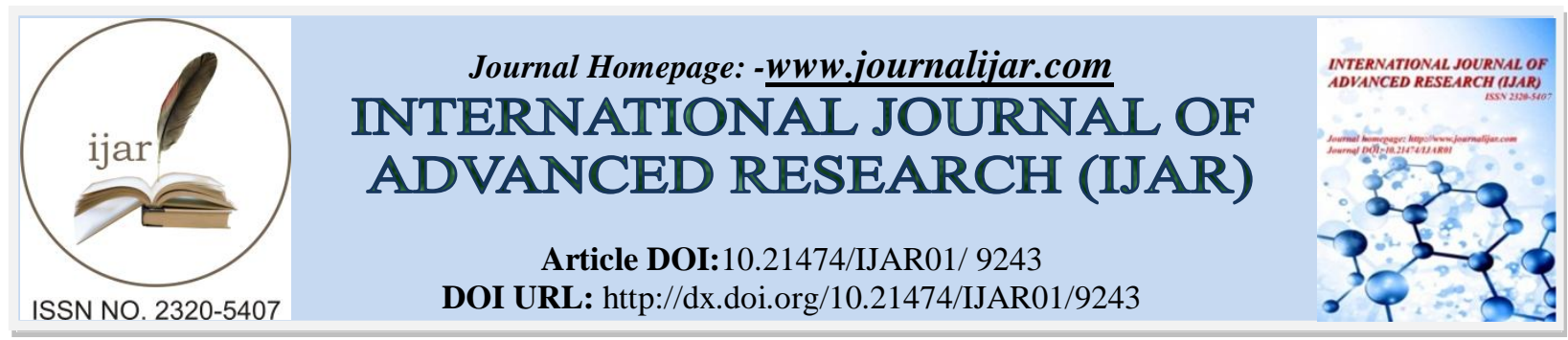

RESEARCH ARTICLE

\title{
ANALYSIS OF TASTE QUALITY OF COFFEA ARABICA L. IN SEVERAL ALTITUDES AT GAYO LUES DISTRICT.
}

Raichan Izzati ${ }^{1}$, Abubakar Karim² ${ }^{2}$, Teti Arabia ${ }^{2}$, Hifnalisa ${ }^{2}$, Manfarizah ${ }^{2}$, Syakur $^{2}$ and Ibnu Hafid ${ }^{3}$.

1. Department of Land Resources Conservation, Post Graduate Program, Universitas Syiah Kuala, Darussalam, Banda Aceh, Indonesia.

2. Department of Soil Science, Faculty of Agriculture, Universitas Syiah Kuala, Darussalam, Banda Aceh, Indonesia.

3. Development Planning Agency, Gayo Lues District, Aceh Province, Indonesia.

\section{Manuscript Info}

Manuscript History

Received: 08 April 2019

Final Accepted: 10 May 2019

Published: June 2019

Key words:-

Arabica Coffea L., Gayo Lues district,

altitude place, potassium content,

speciality coffee.

\section{Abstract}

The quality of arabica coffee taste is determined by varieties, altitude, land cultivation, fermentation, drying, roasted, brewed, and potassium content in the seeds. This study aims to find out the Arabica coffee taste in Gayo Lues district planted on different characteristics of land morphology. The plant sampling was collected and determined by altitude places, different slope, similar varieties, similar age, and similar land cultivation. The total sample was observed from 3-5 plants of Arabica Coffea L. seeds in every unit observation. Parameter of observation was Arabica coffee taste in each altitude places. Variables of Arabica coffee taste that observed were aroma, flavor, after taste, acidity, body, balance, uniformity, clean cup, sweetness, overall, defect, and total score. One of the variables of determinant taste was altitudes place. The best taste was obtained from observation land unit (LU) 21 in scoring 83,75. The research results indicated that there was a positive relationship between altitude place and potassium content to Arabica coffee taste.

Copy Right, IJAR, 2019,. All rights reserved.

\section{Introduction:-}

Arabica coffee has long been a leading commodity in Aceh Province. Center of Arabica coffee Aceh was in highlands of Gayo (Dataran Tinggi Gayo (DTG), consisting of Aceh Tengah district, Bener Meriah district, and Gayo Lues district. These three districts were already widely known as the largest Arabica coffee producing center in Indonesia. The total areas of Arabica coffee in Aceh Tengah reached 51,000 hectares, and cultivated by 32,000 families. with the dry seed productivity about $870 \mathrm{~kg}$ per hectare. In Bener Meriah the total areas of Arabica coffee reached 46,000 hectares and cultivated by 28,000 families, with the productivity almost similar with Aceh Tengah district, as for Gayo Lues district is about 4,000 hectares and cultivated by 2,650 families, with the productivity of dry seeds $650 \mathrm{~kg}$ per hectare. Gayo Lues Regency has an area of 4,000 ha of Arabica coffee plantation, and has the potential to develop 80,212.83 ha of Arabica coffee. The potential for developing Arabica coffee will affect the development and trade of Arabica coffee.

Arabica coffee trade develops rapidly. In the beginning, the Arabica coffee trade was less attention to the quality of 
flavor, but only the physical qualities of coffee beans. Fortunately, recently the quality of flavor Arabica coffee is a great impact in the commerce, some traded under the various special coffee (styles) such as commercial coffee at the value of the score under 70, premium coffee with score 70-80, specialty coffee with score in over 80 and defect seeds less than $4 \%$, luwak, wine, etc. The taste quality of arabica coffee influenced by various environmental factors, namely: varieties, altitudes place in planting, land cultivation, crops management, and post-harvest handling such roasted, poured and served (Hifnalisa and Karim, 2008).

There were three varieties that cultivated by farmers in the of Gayo highlands, namely Gayo 1, Gayo 2, and Ateng super. The varieties Gayo 1 and Gayo 2 have already delivered by Dinas Perkebunan Aceh Tengah (Plantation Office of Aceh Tengah Regency) in 2010 as new varieties. While the variety of Ateng super was the introduction superior variety included to Catimor group. Coffee with a unique taste would be obtained if certain varieties are planted at particular altitude place, without mixed with many other varieties.

The cultivation of Arabica coffee L. in Gayo Lues district located in the mountains area with an elevation place diverse $800-1.300 \mathrm{~m}$ above mean sea level (AMSL). The quality of taste was measured or observed with the criteria such as varieties, age, shading, and crops management. The quality of Arabica coffee taste produced by farmers varied with different elevation (altitudes). The previous research has shown that the altitude affected the quality of physical and coffee flavor (Silva et al., 2015).

The altitude affects air temperature and rainfall. The higher place has the lower the temperature of the air and rainfall with the altitude of a particular place and their land more infertile (Beusekom et al., 2015). The second amendment of climate factors would have an impact on the process of the decomposition of organic substances and chemical composition in the ground and the process of ripening fruit (Somporn et al., 2012). Information on the character of land can be used as advocate on behalf of the choice of location for the development of an Arabica coffee $L$. with the best flavor in Gayo Lues district.

The altitude affects air temperature and rainfall. The higher the place, the lower the temperature and the higher the rainfall with the height of a particular place and the more fertile the land (Beusekom et al., 2015). Changes in the two climate factors will have an impact on the process of decomposition of organic matter and chemical composition in the soil and fruit ripening process (Somporn et al., 2012). Information about the properties of soil can be used as a guideline in the selection of locations for the development of Arabica coffee for communities with the best flavor in the Gayo Lues District.

The research aims to analyze the relationship between the altitudes and soil chemical properties against the quality of Arabica coffee taste in Gayo Lues district. The coffee sample collection and morphology land observation were conducted in Gayo Lues district. Analysis of coffee flavor was tested by Gayo Cupper Team, Bener Meriah. This study has been completed from November 2018 to January 2019.

To establish the site of observation, the research used maps of space allocation based on spatial planning of Gayo Lues district, soil type map, altitude map, slope map, and land use map. The soil samples were collected from each land unit observation then carried out to laboratory to analyzed the $\mathrm{pH}$ of the soil and exchangeable of potassium (Kexch).

The Climate data was collected from Agriculture and Plantation Ministry, Aceh Province and Central Bureau of Statistics Aceh Province. The climate type in the study areas was D1 and B. The total of rainfall, wet months, and dry months are about 2.182,74 mm, 7-8 months and 2-3 months consecutively. Generally, Arabica coffee preferred annual rainfall about 1,500-2,000 $\mathrm{mm}$ and the dry month was about $2-3$ (Karim, et al., 2009). Whereas according to Pujianto (1991), the suitable rainfall for Arabica coffee is $1,000-3,000 \mathrm{~nm}$ per year.

For purposing the analysis of arabica coffee taste, the sample of coffee bean was processed through the steps as follows: (1) the skin of arabica coffee bean was peeled, (2) the peeled coffee bean was fermented for 12 hours (Yusianto and Sukrisno, 2013), (3) the fermented bean was placed into a bucket for washing with fresh water, (4) the beans were dried until the content of water reached 30-40\%, the dried beans were peeled again to obtain the clean bean and dried again until the content of water reached 12-14\%. To analyze of the taste quality, the arabica coffee beans (blind sample) were analyzed in Taste Analyzed Laboratory (Laboratory Uji Citarasa) Gayo Cuppers Team, Bener Meriah. 
The test-cup in the laboratory Gayo Cuppers Team, Bener Meriah was done by the professional test-cup tester (consisted of three experts test-cup) for examining the coffee taste organoleptically (score system). The taste variables scoring observed were: (1) fragrance/aroma, (2) flavor, (3) after taste, (4) acidity, (5) body, (6) balance, (7) uniformity, (8) clean cup, (9) sweetness, (10) overall, (11) defects, (12) taint and fault, and (13) total/final score. The evaluation refers to the Indonesian National Standards-(SNI) 01-2907-1999.

All variables which had been analyzed and scored were associated with altitudes and land morphology parameters. The data analysis was done by comparing the total score of each Arabica coffee taste.

\section{Result and Discussion:- Land Morphology}

Based on altitude place 800 - 2,000 m AMSL, and slope <40 \% parameters of land morphology, the potential areas for arabica coffee development in Gayo Lues district is 80,212.83 ha. The land morphology in the areas of arabica coffee cultivated by the communities has four levels of altitude and five characteristics of slope, with various colors of soil, namely: dark yellowish brown color (10YR 4/6), dark yellowish brown color (10YR 4/4), yellowish brown (10YR 5/6), dark brown color (10YR 3/3), greatly dark brown color (7,5YR 4/6), and strongly dark brown color (10YR 2/2). Overall, the areas had a dark color of top soil horizon.

The varieties of arabica coffee that cultivated by the community were highly varied and planted in one large area simultaneously which resulted of arabica coffee taste quality in Gayo Lues district was not unique. Hence, the varieties should be cultivated based on ideal/suitable altitude habitat. According to Wahyuni., et al (2013), the high score of varieties arabica coffee taste in conjunction with altitude showed that varieties Gayo 2 (> 1.400 m AMSL), varieties Gayo 1 (< $1.200 \mathrm{~m}$ AMSL) and varieties Ateng super (1.200 - $1.400 \mathrm{~m} \mathrm{AMSL})$. The taste test that conducted in Gayo Lues district was only in varieties Gayo 1 cultivated at different altitudes. Varieties Gayo 1 was crossing task between Arabica coffee and Robusta coffee. The varieties have best physical qualities such as seeds size, seeds color, etc. (Karim et al, 2009). Thus, those were favored by the traders which affected many farmers cultivate the variety in Gayo highlands. Karim et al. (2009) stated that varieties Gayo 1 (Tim-tim) have the best taste (unique or specialty).

\section{The Processing of Arabica coffee}

The processing method of Arabica coffee that harvested was local wash. Generally, those local wash even plucking selective on coffee berries can improve the quality of coffee beans physically or tastefully. After plucking, coffee berries were shelled directly with using fulfing machine and then fermented for \pm 12 hours. The fermentation process was carried out more than 7 days effecting chemical changes intensively that cause more compound precursor of an organic acid, an amino acid, and sugar reduction were formed. As a result, a growing amount of volatile and nonvolatile taste compound was formed by a Maillard's reaction after filtering process influences taste and fragrance coffee (Cecilia et al., 2012). During the fermentation process would be occurred a reduction organic substance such as protein and carbohydrates (Murthy and Naidu, 2011).

The local wash process was involving two times of drying process. If residue of moist coffee until 11-12\% when drying process, it should be in the local wash process up to $30-40 \%$ in moist coffee before paring until obtained seeds. The coffee beans then dried deeply before saving. This coffee process have higher rates of sweetness intensely, full body, and acidity less than coffee with washing process (Elida et al., 2010).

The roasting process is the process of forming the taste and aroma of coffee beans. If coffee beans have uniformity in size, specific gravity, texture, moisture content and chemical structure, the roasting process would be relatively easier to control. In fact, coffee beans have a huge difference, so the roasting process was an art and require skills and experience as consumers demand. According to the results of the research by Kaswindi et al. (2017), yield, moisture content, and acidity of Gayo Arabica coffee were significantly influenced by temperature and length of roasting, the highest yield was obtained at $160{ }^{\circ} \mathrm{C}$ and roasting time of 15 minutes is $85.2 \%$, the water content in Gayo Arabica coffee qualify the standards SNI maximum $7 \%$, and the highest acidity $(\mathrm{pH})$ is obtained at $160^{\circ} \mathrm{C}$ for 15 minutes of roasting time (4,95). Further explained, based on the organoleptic test indicated that Gayo Arabica coffee was preferred by a panelist that obtained 170 and $180^{\circ} \mathrm{C}$ with 25 minutes roasting time.

Arabica Coffee Taste Quality in Gayo Lues District

Arabica coffee from Aceh and North Sumatra Province is a specialty Arabica coffee and has high market demand 
because it has a unique characteristic (Ottaway, 2007). Specialty coffee is the term introduced by Erna Knutsen, founder of the Knutsen Coffees Ltd., coffee company in San Francisco, United States (stated by Tea and Coffee Trade Journal in 1974). The concept was very simple, by utilizing micro climate affected by special geographical structure to produce coffee beans which has unique flavors (Rhinehart, 2009). The Indonesian Ministry of Agriculture (2010) defines that the specialty coffee is the coffee that has a distinctive taste, growth in a distinctive area, and has been known by the international community. Lewin et al. (2004) indicated that specialty coffee refers to different coffee from ordinary coffee because of its high quality or the production process differently.

The performance of the taste quality of Arabica coffee beans was a consumer demand that must be provided by producers and exporters. The altitude of Arabica coffee cultivation was one indicator that can affect the taste of Arabica coffee in addition to varieties, processing (fermentation), and roasting. The analysis results of Arabica coffee taste in Gayo Lues district are presented in Table 1. Each of the quality criteria for Arabica coffee beans taste can be explained as follows:

\section{Aroma/Fragrance}

The aroma was recognized through the coffee fragrance when it is brewed with hot water. The result of the study showed that from 11 land unit observations, only the land unit 21 which is located at the altitude of 1,200 - 1,300 m AMSL, has the best Arabica coffee taste based on the aroma criteria, with the score of 8.00 . Whereas the lowest aroma flavor score (7.00) was found at an altitude of 1,000-1,100 m AMSL.

Table 1:-Arabica Coffee Taste Quality affected by altitude and slope at various land unit in Gayo Lues district

\begin{tabular}{|l|c|c|c|c|c|c|c|c|c|c|c|}
\hline No. Land Unit & 1 & 2 & 4 & 8 & 9 & 11 & 14 & 15 & 18 & 20 & 21 \\
\hline $\begin{array}{l}\text { Altitude } \\
\text { (m AMSL) }\end{array}$ & $900-$ & $800-$ & $900-$ & $1,100-$ & $1,000-$ & $1,000-$ & $1,000-$ & $1,000-$ & $1,200-$ & $1,200-$ & $1,200-$ \\
\hline Slope (\%) & $<8$ & 800 & 1,000 & 1,200 & 1,100 & 1,100 & 1,100 & 1,100 & 1,300 & 1,300 & 1,300 \\
\hline Aroma & 7.50 & 7.75 & $26-40$ & $<8$ & $8-15$ & $<8$ & $16-25$ & $26-40$ & $16-25$ & $<8$ & $26-40$ \\
\hline Flavor & 7.50 & 7.75 & 7.75 & 7.25 & 7.50 & 7.50 & 7.25 & 6.75 & 7.75 & 7.25 & 7.75 \\
\hline After Taste & 7.50 & 7.50 & 7.50 & 6.75 & 7.25 & 7.50 & 7.50 & 6.50 & 7.50 & 7.25 & 7.50 \\
\hline Acidity & 7.25 & 7.50 & 7.50 & 7.25 & 7.25 & 7.25 & 7.50 & 6.75 & 7.25 & 7.50 & 7.50 \\
\hline Body & 7.50 & 7.75 & 7.50 & 7.50 & 7.50 & 7.50 & 7.50 & 7.50 & 7.75 & 7.50 & 7.75 \\
\hline Balance & 7.25 & 7.25 & 7.50 & 7.00 & 7.25 & 7.25 & 7.25 & 6.75 & 7.50 & 7.00 & 7.50 \\
\hline Uniformity & 10.00 & 10.00 & 10.00 & 10.00 & 10.00 & 10.00 & 10.00 & 10.00 & 10.00 & 8.00 & 10.00 \\
\hline Clean Cup & 8.00 & 10.00 & 10.00 & 0.00 & 10.00 & 10.00 & 0.00 & 0.00 & 10.00 & 0.00 & 10.00 \\
\hline Sweetness & 10.00 & 10.00 & 10.00 & 10.00 & 10.00 & 10.00 & 10.00 & 10.00 & 10.00 & 10.00 & 10.00 \\
\hline Overall & 7.50 & 7.50 & 7.50 & 7.25 & 7.50 & 7.25 & 7.00 & 6.75 & 7.50 & 7.50 & 7.75 \\
\hline Fault & 0.00 & 0.00 & 0.00 & 0.00 & 0.00 & 0.00 & 0.00 & 20.00 & 0.00 & 0.00 & 0.00 \\
\hline Taint & 0.00 & 0.00 & 0.00 & 10.00 & 0.00 & 0.00 & 10.00 & 0.00 & 0.00 & 2.00 & 0.00 \\
\hline Total Score & 80.00 & 83.00 & 82.75 & 60.25 & 81.75 & 81.75 & 61.75 & 48.00 & 83.00 & 67.75 & 83.75 \\
\hline
\end{tabular}

\section{Flavor}

The flavor can be known by sipping coffee and tasted in all parts of tongue and oral cavity. The act of sipping hard and deep so that coffee can be assessed for flavor, requires maximum sense and sensory work because flavor describes the main character of the coffee. From the 11 land units that were evaluated, the best taste of Arabica coffee based on flavor criteria was found at land unit 2, 4, 18, and 21 at with the altitude of $800-1,000 \mathrm{~m}$ AMSL and 1,200 - 1,300 m AMSL with the score of 7.75. The lowest flavor was found at land unit 15 with an altitude of 1,000-1,100 m AMSL. With the score of 6.75. According to Malau et al. (2017) the difference of place or district showed significant effect to fragrance/aroma, flavor, afertaste, acidity, body, balance, overall, and total score in sweetness and 100 green bean weight.

\section{After Taste}

The after taste is assessed by the coffee has been sipped then released back, and waited a few moments. If the tongue still senses the coffee flavor means that the after taste value was good. The result showed that best taste of Arabica coffee based on after taste criteria was found on land unit 1,2, 4, 11, 14, 18, and 21 with the score of 7.50. The lowest after taste score was found on land unit 15 at altitude of 1,000 - 1,100 m AMSL with the score of 6.50. 


\section{Acidity}

Testing is also carried out for acidity to Arabica coffee. The level of authenticity can be received by the tongue assessed by an examiner. The result of the study indicated that the best taste of Arabica coffee based on acidity taste criteria was found on land unit 2, 4, 14, 20, and 21 with the score of 7.50. The lowest acidity taste score was found on 15 with altitude 1,000 - 1,100 m AMSL with the score of 6.75. The organic acid content in coffee beans was very important because of its role as a compound that contributes to form the quality of taste, especially for acidity components in brewed coffee (Taba, 2012). In addition, organic acids also play a role in the formation of ester compounds, namely volatile compounds which form the coffee aroma (Somporn et al., 2011).

\section{Body}

The body can be interpreted as heavy and light tastes of coffee when it is sipped. The heavier tastes of coffee the better body rating of coffee. The result showed that the best taste of Arabica coffee based on the taste criteria of the body was found on land unit 2, 18, and 21 at altitude of 800 - $900 \mathrm{~m}$ AMSL. and 1,200 - 1,300 m AMSL with the score of 7.75. Then followed by the body flavor score was 7.50 on the other land unit.

\section{Balance}

Balance can be interpreted as a combination of parameters flavor, aftertaste, acidity, and body. The coffee that has the nearly score of the parameters has a good balancing score. If there is one or more have dominant aspect, such flavor, the balancing value is reduced. The result of the study showed that the best Arabica coffee flavors based on balanced taste criteria was found on land unit 4, 18, and 21 at altitude $900-1,000 \mathrm{~m}$ AMSL. and 1,200 - 1,300 m AMSL. with the score of 7.50. While the lowest taste balance score was found on land unit 15 at an altitude of 1,000 - 1,100 m AMSL. with the score of 6.75 .

\section{Uniformity}

Uniformity was tasted with five cups/bowl coffee sample. If in one bowl has difference flavor, the score was 8 . If those are all similar, the uniformity taste score was 10, the perfect score. The result showed that that the lowest Arabica coffee taste based on uniformity taste criteria was found on land unit 20 at attitude 1,200 - 1,300 m AMSL. with the score of 8.00, while the uniformity taste score on the remaining land unit SPL was 10.00.

\section{Clean Cup}

Clean cup, a positive taste or cleanliness. There was no taste disturbance from flavor to aftertaste testing. The taste starts from the beginning of sipping to throw it away. The result shoed that the best taste of Arabica coffee based on the taste criteria of clean cup was found on land unit 2, 4, 9, 11, 18 and 21 with the score of 10.00, while the lowest clean cup taste score found on land unit 8,14, 15 and 20 at altitudes of 1,000 - 1,200 m AMSL and 1,200 - 1,300 m AMSL with the score of 0.00 .

\section{Sweetness}

The sweetness was flavor fullness of the coffee samples tested, usually defined as sweetness. The result showed that the Arabica coffee taste based on score of sweetness taste criteria was 10.00 for all observed land unit.

\section{Overall}

The assessment aspect was based on the examiner's personality. It means that the examiner willing or not the coffee taste. The scored was ranged from 1 to 10. The result showed that the best Arabica coffee flavor was based on the overall flavor score was found on land unit 21 at attitude of 1,200 - 1,300 m AMSL with the score of 7.75, while the lowest score was found on land unit 15 at altitude of 1,000-1,100 m AMSL with the score of 6.75.

\section{Defects (Taint and Fault)}

Negative or defective scent reduces the coffee quality such as taint and fault. The taint and fault scores from land unit 8, 14, and 20 were $10.00,10.00$ and 2.00 consecutively, while fault score in land unit 15 was 20.00. The taint and fault can be caused by defected coffee beans. The results of the data survey in $2004-2013$ showed that the level of defected coffee beans tended to increase in recent 10 years. Thus, there was a pest attack which resulted in a decrease in the coffee beans quality. The defected coffee bean was also caused by Fusarium sp. which begins with the attack of the Hypothenemus hampei's. The symptoms arise from this fungus in the wilt form, rotten fruit, dumping off and rot on the seeds. This disease mostly occurs in humid gardens, lack of pruning and tight shading (Syahril, 2016). 


\section{Total score}

All aspects have been assessed then summed up and re-evaluated. If the score of 8 means that the sample of Arabica coffee included in the specialty coffee. The result showed that there were seven land units, namely land unit $1,2,4$, $9,11,18$, and 21 were included in the specialty coffee. The land unit 21 at altitude of 1,200 - 1,300 m AMSL showed the highest total taste score of 83.75 .

Asfirmanto et al. (2013) pointed out that the total score given for Gayo Arabica coffee was 85.4 with the number of components affected by cultivation was 54.3 and the number of component scores affected by the physical condition region was 24.1 with a panelist correction of 7.0. Those scores showed that cultivation has an impact of $63.5 \%$ on the total cupping score, while the physical condition area has an impact of $28.2 \%$. Based on each component, both of the physical condition area and cultivation, the physical condition area has a role $9.4 \%$, while cultivation has $9.1 \%$ of each component. Thus, the component of physical condition of the region has a greater role rather than cultivation process, even though it was not significant to the quality of Gayo Arabica coffee.

The physical condition of area where the arabica coffee cultivated would affect the components such as acidity, taste, and aftertaste. The cultivation practices influence the components of dry fragrance, the aroma before and after drinking of coffee, viscosity level, sweetness, positive taste, coffee flavor combination, and consistency of coffee in several cups. Malau et al. (2018) said that Arabica coffee genotypes affected seed germination ability. Seed germination ability was more affected by elevation of seed producing location rather than by precipitation and temperature

\section{Relationship between Land Characteristic and Arabica Coffee taste Quality}

The taste quality of Arabica coffee is assumed and related to the characteristics of the land. To determine the effect of land characteristics on Arabica coffee flavor, multiple linear regression tests were conducted to determine the effect of variable X; altitude (X1), slope (X2), $\mathrm{pH} \mathrm{H}_{2} \mathrm{O}(\mathrm{X} 3)$, and K-dd (X4) on Y; Final score of Arabica coffee (Y) in Gayo Lues district. The result showed that the altitude and K-dd content correlated arabica coffee taste quality.

The equation of multiple linear regression analysis between the land characteristics and arabica coffee taste was: $\mathrm{Y}=$ $66.767+1.790 \mathrm{X} 1+7.380 \mathrm{X} 4(\mathrm{R} 0.306)$. There was a positive relationship between altitude and the K to Arabica coffee taste. An increase in altitude of $100 \mathrm{~m}$ AMSL could increase the taste quality score of 1,790, while an increase $\mathrm{K}$ content of $1 \mathrm{me} / 100 \mathrm{~g}$, could increase the taste quality score 7,380. The $\mathrm{K}$ content plays an important role in protein synthesis, carbohydrates, and adenosine triphosphate (ATP), regulation of osmotic pressure, and tolerance to pests and diseases through the effects of the durability and permeability of plasma membranes (Marschner, 2012 cited by Moura et al., 2015). Potassium content determines the flavor quality by activating the polyphenol oxidase enzyme and controls the caffeine and phenol content in coffee beans (Clemente et al., 2015).

\section{Conclusion:-}

There were seven land units included in the specialty coffee, namely land unit 1, 2, 4, 9, 11, 18, and 21. The land unit 21 with altitude of 1,200 - 1,300 m AMSL resulted the highest total taste score (83.75). There was a positive relationship between altitude, and $\mathrm{K}$ content to the Arabica coffee taste with the formula $\mathrm{Y}=66.767+1.790 \mathrm{X} 1+$ 7.380X4 (R 0.306).

\section{Reference:-}

1. Asfirmanto, W.A., T. Nurlambang, T. Watyono. 2013. Effects of Physical Conditions and Cultivation on Coffee Quality in Kintamani and Gayo. Faculty of Mathematics and Natural Sciences (FMIPA). University of Indonesia.

2. Beusekom, V.A.E., G. González., and M.M Rivera. 2015. Short-term precipitation and temperature trends along an elevation gradient in Northeastern Puerto Rico. Earth Interactions., Vol. 19(3): 1-33.

3. Cecilia, K., Glanton, K., Simon, M., Renaud, B., dan Fredrick, N. 2012. Volatile organic compounds in brewed Kenyan arabica coffee genotypes by solid phase extraction gas chromatography-mass spectrometry. Food Science and Quality Management., Vol. 8 (1) 8-22.

4. Clemente, J.M., H.E.P Martinez., L.C. Alves., F.L., Finger., dan P.R. Cecon. 2015. Effects of nitrogen and potassium on the chemical composition of coffee beans and on beverage quality. Maringá., Vol: 37(3): 297305. 
5. Elida, N., Rizal, S., Erliza, N., and Sri, M. 2010. Improving the quality of coffee beans with semi-wet processing based on clean production. J. Agrotek., Vol. 4 (1): 76-90.

6. Hakim, N., M. Y. Nyakpa, A.M. Lubis, S.G. Nugroho, M.S. Saul, M.A Diha, Go Ban Hong and H.H Bailey. 1986. Principles of Soil Science. University of Lampung. Lampung

7. Karim, A., and Hifnalisa. 2008. Preliminary study of Arabica coffee varieties based on altitude in the Gayo Highlands. Agrista Journal. December 2008 Special Edition: 162-172.

8. Karim, A., Darusman., Hifnalisa, and Khalid. 2009. Tracking of Arabica Coffee Superior Varieties that Have Unique Flavors from several Altitude Places and Methods of Processing in the Gayo Highlands. Competitive Region Superior Research Report. Faculty of Agriculture. Syiah Kuala University..

9. Kaswindi., Bambang, S. P., Rita, K. 2017. Study of the quality of Gayo Arabica coffee with variations in temperature and length of roasting. Agricultural Student Scientific Journal, Vol. 2 (2): 416-422.

10. Leiwakabessy, F.M., and A. Sutandi. 2004. Fertilizer and Fertilization. Lecture Material on Soil Science Department. Faculty of Agriculture. Bogor Agricultural Institute.

11. Lewin, B., D. Giovannucci., and V. Panayotis. 2004. Coffee markets: New Paradigms in Global Supply and Demand. World Bank Agriculture and Rural Development Discussion Paper 3. Washington, DC: World Bank. doi:10.2139/ssrn. 996111.

12. Ministry of Agriculture. 2010. General Guidelines for Implementation of Organic Coffee Development / Rehabilitation (Specialty) in 2010. Jakarta: Ministry of Agriculture, Directorate General of Plantation.

13. Moura, W.M., Y.J.B. Soares., A.T.A. Júnior., P.C. de Lima., H.E.P. Martinez., G.A. Amaral., and Gravina. 2015. Genetic diversity in arabica coffee grown in potassium constrained environment. Ciênc. Agrotec., Lavras., Vol. 39(1): 23-31.

14. Murthy, P.S., \& Naidu, M.M. 2011. Improvement of Robusta coffee fermentation with microbial enzymes. European Journal of Applied Sciences., Vol. (3): 130-139.

15. Núñez, P.A., Pimentel, A., Almonte, I., Sotomayor-Ramírez, D., Martínez, N., Pérez1, A., \& Céspedes1, C.M. 2011. Soil fertility evaluation of coffee (Coffea spp.) production systems and management recommendations for the Barahona Province, Dominican Republic. J. Soil Sci. Plant Nutr., Vol. 11(1): 127-140.

16. Ottaway, A. 2007. A rapid assessment of the specialty coffee value chain in Indonesia. Michigan: United States Agency for International Development (USAID).

17. Plantation Office of Aceh Province. 2018. Development of Arabica Coffee Prices in Aceh Province. Aceh (ID): Disbun Aceh Province.

18. Pujianto. 1991. Land Suitability for Coffee. Paper presented at the Cultivation Technique and Coffee Processing Training. Jember Plantation Research Center, September 23 - October 16, 1991

19. Rhinehart, R. 2009. What is specialty coffee? Retrieved July 4, 2016, from http://www.scaa.org/?page=RicArtp2.

20. Rika, S. 2017. Study on the Characteristics of Arabica (Arabica coffea) Coffee Powder Based on Temperature and Length of Roasting. Faculty of Agriculture, Syiah Kuala University, Banda Aceh.

21. Malau, S., A Siagian., B Sirait., H. Ambarita. 2018. Germination performance of coffea arabica L. genotypes from different altitude, precipitation and temperature of seeds producing farms in Sumatera Utara of Indonesia. $1^{\text {st }}$ Nommensen International Conference on Technology and Engineering

22. Malau, S., Albiner S., Bilter S, Samse P. 2017. Performance of coffe origin and genotype in organoleptic and physical quality of arabica coffe in North Sumatera Province of Indonesia. $1^{\text {st }}$ Nommensen International Conference on Technology and Engineering.

23. Silva, S. de A., de Queiroz, D. M., Ferreira, W. P. M., Corrêa, P. C., dan Rufino, J. L. dos S. 2015. Mapping the potential beverage quality of coffee produced in the Zona da Mata, Minas Gerais, Brazil. Journal of the Science of Food and Agriculture., Vol (96): 3098-3108. https://doi.org/10.1002/jsfa.7485.

24. Somporn, C., Kamtuo, A., Theerakulpisur, P., dan Siriamompun, S. 2011. Effects of roasting degree on radical scavenging activity, phenolics and volatile compounds of Arabica coffee beans. International Journal of Food Science and Technology., Vol. 46 (9): 2287-2296.

25. Somporn, C., Kamtuo, A., Theerakulpisut, P., dan Siriamornpun, S. 2012. Effect of shading on yield, sugar content, phenolic acids and antioxidant property of coffee beans (Coffea arabica L. cv. Catimor) harvested from north-eastern. Thailand. J. Sci. Food Agric., Vol. 92 (9): 1956-1963.

26. Syahril, M. 2016. Analysis of the Physical Quality Conditions of Gayo Arabica Coffee Beans in the Last Ten Years. Essay. Agricultural Production Technology Department, Faculty of Agriculture, Unsyiah, Banda Aceh.

27. Taba, J. 2012. Coffee taste analysis of an espresso coffee using nuclear magnetic spectroscopy. (Bachelor Thesis Central Ostrobothnia University of Applied Sciences, Eindhoven Holland). 
28. Wahyuni, E., A. Karim., A. Anhar. 2013. Analysis of the taste of organic Arabica coffee at various altitudes and methods of processing it in the Gayo Highlands. Journal of Land Resource Management., Vol. 2 (3): 261-269.

29. Yulius, A.K.P, A.B. Ibrahim, H. Asmadi, J.L. Nanere, J.R. Lalopus, R. Tangkaisari and S.S.P. Samosir. 1985. Basics of Soil Science. Cooperation Agency for East Indonesian State Universities. Ujung Pandang. Thing 173176, 181-182.

30. Yusianto and W. Sukrisno. 2013. Quality and Taste of Arabica Coffee from several Fermentation Treatments: Temperature, Container Type, and Addition of Fermentation Agents. J. Pelita Perkebunan., Vol. 29 (3): 220239. 